\title{
Physiological and Biochemical Characteristics of Some Strains of Sulphate-reducing Bacteria
}

\author{
By J. D. A. MILLER* AND JANET E. HUGHES \\ National Physical Laboratory, Teddington, Middlesex, England \\ AND G. F. SAUNDERS AND L. L. CAMPBELL \\ Department of Microbiology, University of Illinois, Urbana, Illinois, 61801, U.S.A. \\ (Accepted for publication I December 1967)
}

\begin{abstract}
SUMMARY
Fourteen previously unstudied strains of the genus Desulfovibrio and eight thermophilic strains of the genus Desulfotomaculum were allotted to species on the results of physiological and biochemical tests.

On DNA base composition the Desulfovibrio strains fell clearly into three groups, corresponding to $D v$. salexigens, $D v$. desulfuricans and $D v$. vulgaris. $\mathrm{NaCl}$-dependence appeared to be a constant and unique feature of $D v$. salexigens strains, and 'sulphate-free' growth on pyruvate a constant characteristic of $D v$. desulfuricans, although one strain of $D v$. vulgaris also dismuted pyruvate. Fumarate dismutation showed no species correlation. 'Sulphatefree' growth on choline was often minimal and the test appeared to be of little value. A high degree of resistance to Hibitane was not a constant characteristic of $D v$. salexigens.

The thermophilic strains showed great uniformity in DNA base composition, Hibitane resistance and 'sulphate-free' growth, and were all classified as Desulfotomaculum nigrificans.
\end{abstract}

\section{INTRODUCTION}

Saunders, Campbell \& Postgate (I964) showed that 30 strains of non-sporulating dissimilatory sulphate-reducing bacteria could be divided into three groups defined by their deoxyribonucleic acid (DNA) base composition. With these and other data in mind, the classification of the dissimilatory sulphate-reducing bacteria was revised (Campbell \& Postgate, 1965; Campbell, Kasprzycki \& Postgate, I966; Postgate \& Campbell, I966). The sporulating members were placed in a new genus, Desulfotomaculum, represented by three species: Dt. nigrificans, Dt. ruminis and Dt. orientis (Campbell \& Postgate, 1965). The non-sporulating members were placed in the genus Desulfovibrio, represented by five species: Dv. desulfuricans, $D v$. vulgaris, Dv. salexigens, Dv. gigas and Dv. africanus (Campbell et al. 1966; Postgate \& Campbell, 1966).

The present paper reports the results of a study of the physiological and biochemical characteristics of I 4 previously unstudied strains of the genus Desulfovibrio and eight thermophilic strains of the genus Desulfotomaculum.

* Present address: Department of Chemical Engineering, University of Manchester Institute of Science and Technology, Manchester I. 


\section{METHODS}

Organisms. The following 22 strains of sulphate-reducing bacteria were obtained as ampoules of freeze-dried material from the National Collection of Industrial Bacteria, Torry Research Station, Aberdeen, Scotland (NCIB):

(I) Mesophilic strains (non-sporulating; growth temperature $30^{\circ}$ ). (a) Salt-water strains: NCIB 8309 (EL AGHEILA A), 8315 (NEW JERSEY SW-8), 8316 (NEW JERSEY SW-3), 8326 (CALIFORNIA 29:I37:5), 8396 (EL AGHEILA 4), 8399 (VENEZUELA), 8400 (HOSSEGOR), 8402 (EL AGHEILA 2) and 9492 (ABERDOVEY). (b) Fresh-water strains: 8456 (DENMARK, a morphologically unusual strain showing predominantly long spirillar forms), 8457 (WOOLWICH) and 8458 (BYRON).

(2) Thermophilic strains (fresh-water strains; spore-bearers; growth temperature 55 ): 8356 (HOLLAND CT), 8357 (DELFT 48 T), 8359 (DELFT 3 T), 8360 (DELFT I3 T), 836I (DELFT I5 T), 8394 (DELFT I T), 8706 and 8788 (unnamed strains).

Cultivation. Cultures were grown anaerobically, from freeze-dried specimens, at $30^{\circ}$ or $55^{\circ}$ as appropriate, in the medium of Baars (1930) containing I.0 g. Difco yeast extract/1. and $5 \mathrm{~mm}$-cysteine hydrochloride. $\mathrm{NaCl} 25^{\circ} \mathrm{g}$./1. was added for the saltwater organisms. Details of the preparation, sterilization and $\mathrm{pH}$ adjustment of this medium were as given by Saleh, Macpherson \& Miller (I964). After revival, stock cultures of the mesophilic strains were maintained in the medium C of Butlin, Adams \& Thomas (1949) as modified by Professor J. R. Postgate (see Baker, Papiska \& Campbell, I962), and subcultured weekly. The thermophilic strains gave better growth in Baars medium, in which stock cultures were therefore maintained. Stock and experimental cultures were grown in Pyrex test tubes or flasks plugged with cottonwool and incubated in McIntosh and Fildes anaerobic jars in an atmosphere (except when stated otherwise) of $99 \%(\mathrm{v} / \mathrm{v}) \mathrm{H}_{2}+\mathrm{I} \%(\mathrm{v} / \mathrm{v}) \mathrm{CO}_{2}$.

Stock cultures, and all experimental cultures except those in the Hibitane test, were tested for aerobic and anaerobic contaminants (Postgate, 1953).

Pigment detection. For cytochrome $c_{3}$ demonstration, fully grown $200 \mathrm{ml}$. cultures in medium $\mathrm{C}$ were concentrated by centrifugation and examined with the Hartridge reversion spectroscope after the addition of sodium dithionite. A strong absorption band at about $554 \mathrm{~m} \mu$ and a weaker one at $525 \mathrm{~m} \mu$ indicated the presence of cytochrome $c_{3}$. Desulfoviridin was tested for by the method of Postgate (1959a).

Maximum growth temperature. In view of the significance of thermophily in the taxonomy of sulphate-reducing bacteria, the limiting growth temperature was determined for the strains stated by the NCIB to be mesophilic. Test-tube cultures in medium $\mathrm{C}$ were incubated in anaerobic jars immersed in a thermostat tank initially at $37^{\circ} \pm 0 \cdot 2^{\circ}$; the maximum growth temperature was observed by making serial subcultures with incubation temperature increments of $0.5^{\circ}$.

Resistance to Hibitane. The bacteriostatic concentration of Hibitane (Imperial Chemical Industries Ltd., Wilmslow, Cheshire) towards each strain in Baars medium was determined by the method of Saleh (1964).

Adaptation to growth in salt-water or freshwater media. Serial subcultures of the mesophilic strains were made in medium $C$ with increments or decrements of $5 \cdot 0 \mathrm{~g} . / 1$. in $\mathrm{NaCl}$ concentration. Three successive subcultures were made in the final medium before adaptation was considered to be proved. In later stages of the experiment, 
growth often took more than a week to appear; results were therefore not recorded as negative until three weeks after inoculation.

Pyruvate dismutation test. Strains were examined for sulphate-free growth by using the pyruvate medium of Postgate (1963a) containing cysteine hydrochloride. The sodium pyruvate used was recrystallized from $80 \%(\mathrm{v} / \mathrm{v})$ ethanol in water. The cultures were incubated under nitrogen. Persistence of growth through five subcultures was taken as evidence of ability to grow by pyruvate dismutation.

Choline utilization. Strains were examined for anaerobic growth (under $\mathrm{N}_{2}$ ) on choline, with and without $26 \mathrm{mM}$-sodium sulphate, by using the medium of Baker $e t$ al. (1962) containing cysteine. The same criterion of substrate utilization was used as in the pyruvate test (smell of trimethylamine is an unsuitable criterion of growth in the case of large numbers of cultures incubated together, since the gas penetrates into cultures in which no growth has occurred).

Estimation of growth. In the pyruvate, choline, and $\mathrm{NaCl}$ adaptation tests, growth was often scanty and therefore difficult to measure turbidimetrically or by microscopic examination. Growth in the final subculture was thus visually graded,- \pm (turbidity just discernible in daylight), or + .

Buoyant density measurements. DNA was isolated and purified as described by Saunders et al. (1964). The buoyant density of the DNA was determined by $\mathrm{CsCl}$ density gradient centrifugation (Saunders et al. 1964) with ${ }^{15} \mathrm{~N}$-labelled Pseudomonas aeruginosa DNA $\left(\rho=\mathrm{I} \cdot 742 \mathrm{~g} . \mathrm{cm}^{-3}\right)$ as a density reference standard. Buoyant densities and base compositions of the DNA were calculated according to the equations of Sueoka (196I).

\section{RESULTS}

All results except those of the pigment tests are summarized in Table I.

Pigment tests. All the mesophilic strains contained cytochrome $c_{3}$ and desulfoviridin; the thermophilic strains contained neither pigment.

Inhibition by Hibitane. Saleh (1964) tested the ABERDOVEY strain against Hibitane and found the bacteriostatic concentration to be $10 \mu \mathrm{g} . / \mathrm{ml}$.; in our experiment with this strain it was $100 \mu \mathrm{g} . / \mathrm{ml}$. None of our strains ascribed to the species Desulfovibrio salexigens on DNA base composition grew in the presence of $50 \mu \mathrm{g}$. Hibitane $/ \mathrm{ml}$. Since the members of this species tested by Saleh resisted $1000 \mu \mathrm{g}$./ml., we checked our experimental technique by re-testing one of the strains of $D v$. salexigens that Saleh had tested (CALIFORNIA 43:63; NCIB 8364). Our result confirmed his finding with this strain.

$\mathrm{NaCl}$ adaptation. Only one strain isolated from a freshwater habitat was unable to grow in $2.5 \%(\mathrm{w} / \mathrm{v}) \mathrm{NaCl}$. At the first attempt this strain (BYRON) did not survive in $2 \% \mathrm{NaCl}$; in a second attempt, starting again with a culture in NaCl-free medium, growth occurred in the presence of $2.0 \% \mathrm{NaCl}$ but not $2.5 \%$.

Pyruvate dismutation. This test was made at Urbana, Illinois, U.S.A., and at Teddington, Middlesex, England; somewhat different results were obtained. In the case of the 'doubtful' dismuter australia and the 'positive' dismuter el AGHELLA A (Teddington results) the fifth subculture was examined microscopically: typical vibrios were seen. The cultures were uncontaminated.

Choline utilization. The whole choline utilization experiment was performed twice. In some cases, growth was obtained in one experiment but not the other; these are 


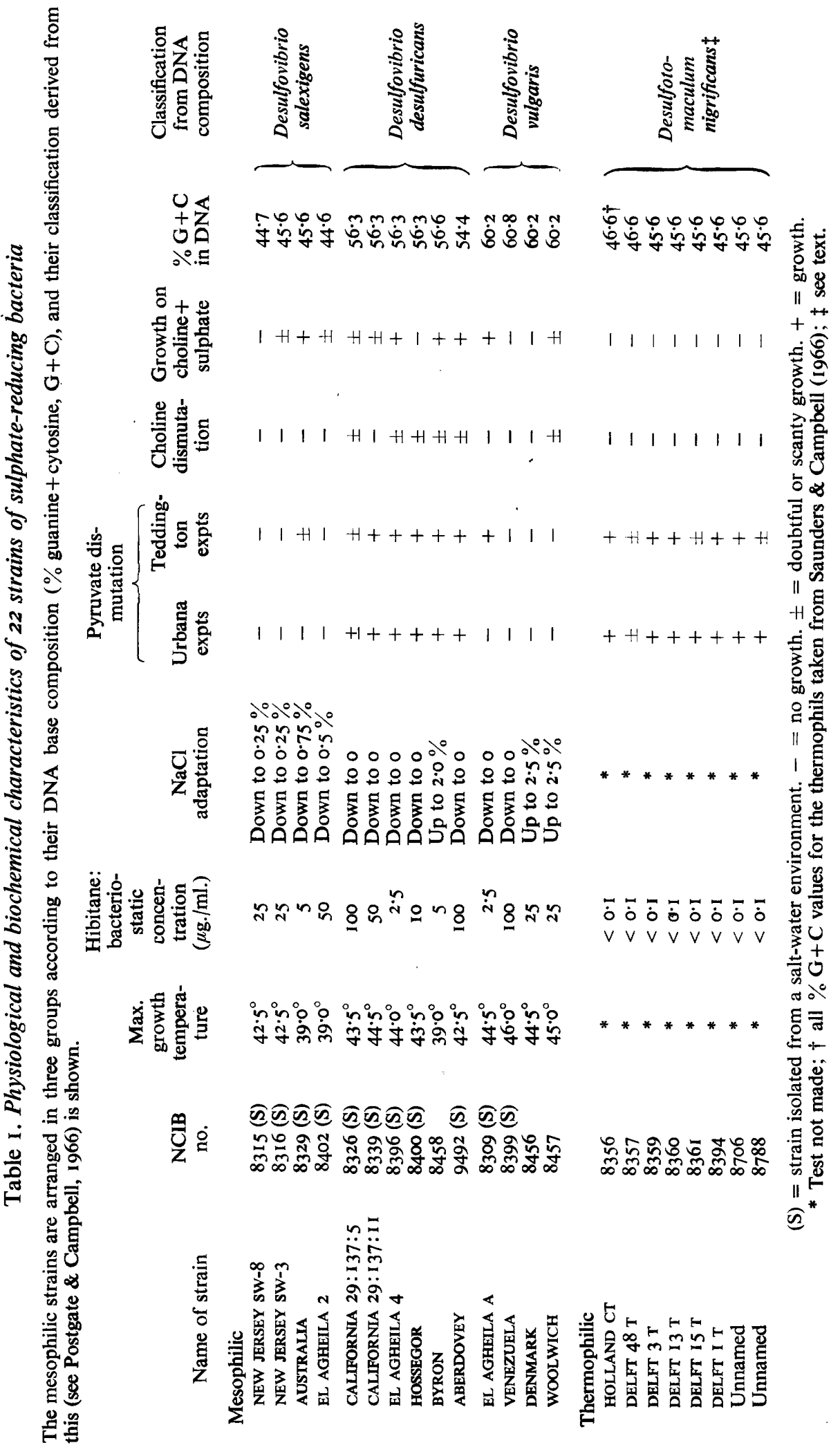


recorded as \pm in Table $I$, as also are strains which gave scanty growth. Some strains, recorded as negative, produced scanty growth and died out on or before the fifth subculture. Where positive growth occurred, it was much less than in sulphate-free pyruvate medium.

DNA-base composition. As judged by DNA base composition all I4 Desulfovibrio strains could be placed in the three groups of Saunders et al. (1964). Both marine and freshwater strains appear in group I ( $60 \%$ guanine + cytosine, $\mathbf{G}+\mathrm{C})$ and group II $(54-56 \% \mathrm{G}+\mathrm{C})$; the obligate salt-water strains all belonged to group III $(45-46 \%$ $\mathrm{G}+\mathrm{C}$ ). The DNA base compositions of the Desulfotomaculum nigrificans strains were reported previously by Saunders \& Campbell (1966).

\section{DISCUSSION}

The physiological and biochemical data show that the I4 strains of non-sporulating dissimilatory sulphate-reducing bacteria studied here belong to the genus Desulfovibrio; by using the taxonomic criteria outlined by Postgate \& Campbell (1966), it was possible to place the strains into three species: $D v$. vulgaris, $D v$. desulfuricans and $D v$. salexigens. The thermophilic sporulating sulphate reducers were identified as Desulfotomaculum nigrificans (Campbell \& Postgate, 1965).

Saleh (1964) reported that the Hibitane resistance of Desulfovibrio strains showed a correlation with the DNA base composition. This apparent correlation did not hold for the strains examined in the present work. Moreover, it has been found that a given strain can show a tenfold variation in its Hibitane resistance at different times (or in the hands of different workers). Thus Hibitane resistance is a less useful taxonomic character for this group of organisms than was originally thought, though very high resistance still predominates in the $D v$. salexigens group and relatively low resistance in the $D v$. vulgaris and $D v$. desulfuricans groups.

The readiness with which our marine and freshwater strains of Desulfovibrio desulfuricans and $D v$. vulgaris could be adapted to grow either in the absence or presence of $\mathrm{NaCl}$ confirms the contention of Postgate \& Campbell (I966) that salt relations are not of taxonomic significance in these two species. Our obligate saltrequiring strains were classified as Dv. salexigens (see Postgate \& Campbell, 1966), though it is interesting that three of our four strains grew at lower $\mathrm{NaCl}$ concentrations than that stated by these authors to be required by $D v$. salexigens ( $>0.6 \%$ ). It was not determined at this stage whether our strains required $\mathrm{Na}^{+}$or $\mathrm{Cl}^{-} ;$a more comprehensive study of the salt relations of this species is under way.

The problems of using carbon source utilization data for speciation in the genus Desulfovibrio were discussed by Postgate (1959b), Macpherson \& Miller (1963), Postgate (1965), and Postgate \& Campbell (1966). The ability to grow on choline or pyruvate in the absence of sulphate appears to separate $D v$. desulfuricans from other species of the genus Desulfovibrio. However, the difficulty in obtaining repeatable results with choline, coupled with the scanty growth of many strains of $D v$. desulfuricans on this substrate, makes the use of this character questionable. Miller \& Wakerley (I966) reported that the ability to grow on sulphate-free fumarate media is possessed by strains which have now been shown to belong to four of the five species of the genus Desulfovibrio. Fumarate dismutation is therefore not a valid taxonomic character for this group of organisms. Thus, except for dismutation of pyruvate, the utilization of carbon substrates does not appear to be useful in characterizing these organisms. 
Strain EL AGHEILA A presents a taxonomic problem similar to that of Postgate's $(1963 b)$ oxamate-utilizing strain MONTICELLO 2 . In its ability to grow on pyruvate in the absence of sulphate, EL AGHEILA A resembles Desulfovibrio desulfuricans; its DNA base composition, however, places it with the $D v$. vulgaris group. We have given greater weight to the DNA base composition and have classified EL AGHEILA A as $D v$. vulgaris (it should be noted that EL AGHEILA A does not utilize oxamate when tested by the method of Postgate, $1963 b$ ).

Our results with Desulfotomaculum nigrificans strains in sulphate-free medium confirm the previous observations of Postgate (I963a) and Akagi (1964) with this species.

With this study of 22 previously unclassified strains, most of the strains of the genera Desulfovibrio and Desulfotomaculum at present available from recognized culture collections have now been examined. The findings are consistent with the working classification schemes proposed for these two genera by Campbell \& Postgate (1965) and Postgate \& Campbell (1966).

We are indebted to Lynette Elford, Mary Vermeulen, Mary A. Kerley, and Francis Engle for excellent technical assistance. G. F. Saunders was a predoctoral trainee in the Microbiology Training Grant Program (GM-5IO) of the National Institute of General Medical Sciences during this work. The Illinois studies were supported by a U.S. Public Health Service Grant to L. L. Campbell (AI-04673) from the National Institute of Allergy and Infectious Diseases. The Teddington studies were part of the General Research Programme of the National Physical Laboratory.

\section{REFERENCES}

AKAGI, J. M. (1964). Phosphoroclastic reaction of Clostridium nigrificans. J. Bact. 88, 813.

BaARs, J. K. (1930). Over sulphaatreductie door bacterien. Dissertation: Delft, Holland; publ. W. D. Meinema.

Baker, F. D., Papiska, H. R. \& Campbell, L. L. (1962). Choline fermentation by Desulfovibrio desulfuricans. J. Bact. 84, 973.

Butlin, K. R., ADAms, M.E. \& Thomas, M. (I949). The isolation and cultivation of sulphatereducing bacteria. J. gen. Microbiol. 3, 46.

Campbell, L. L. \& Postgate, J. R. (1965). Classification of the spore forming sulfate-reducing bacteria. Bact. Rev. 29, 359.

CAmpbell, L. L., KasprzyCKI, M. A. \& Postgate, J. R. (1966). Desulfovibrio africanus sp.n., a new dissimilatory sulfate-reducing bacterium. J. Bact. 92, I 122.

MACPHERson, R. \& MilleR, J. D. A. (I963). Nutritional studies on Desulfovibrio desulfuricans using chemically defined media. J. gen. Microbiol. 31, 365 .

MillerR, J. D. A. \& WAKRRLEY, D. S. (I966). Growth of sulphate-reducing bacteria by fumarate dismutation. J. gen. Microbiol. 43, 101.

Postgate, J. R. (I953). On the nutrition of Desulphovibrio desulphuricans: a correction. J. gen. Microbiol. 9, 440.

Postgate, J. R. (1959a). A diagnostic reaction of Desulphovibrio desulphuricans. Nature, Lond. 183, $48 \mathrm{I}$.

Postgate, J. R. (1959b). Sulphate reduction by bacteria. A. Rev. Microbiol. 13, 505.

Postgate, J. R. (1963a). Sulfate-free growth of Clostridium nigrificans. J. Bact. 85, 1450.

Postgate, J. R. (1963b). A strain of Desulfovibrio able to use oxamate. Arch. Mikrobiol. 46, 287.

Postgate, J. R. (1965). Recent advances in the study of sulfate-reducing bacteria. Bact. Rev. 29, 425.

Postgate, J. R. \& CAmpbell, L. L. (1966). Classification of Desulfovibrio species, the nonsporulating sulfate-reducing bacteria. Bact. Rev. 30, 732. 
SALEH, A. M. (I964). Differences in the resistance of sulphate-reducing bacteria to inhibitors. J. gen. Microbiol. 37, II3.

Saleh, A. M., Macpherson, R. \& Miller, J. D. A. (1964). The effect of inhibitors on sulphatereducing bacteria: a compilation. J. appl. Bact. 27, 28I.

Saunders, G. F. \& CAMprell, L. L. (1966). Deoxyribonucleic acid base composition of Desulfotomaculum nigrificans. J. Bact. $92,515$.

Saunders, G. F., Campbell, L. L. \& Postgate, J. R. (1964). Base composition of deoxyribonucleic acid of sulphate-reducing bacteria deduced from buoyant density measurements in cesium chloride. J. Bact. 87, 1073.

SUEOKA, N. (1961). Variation and heterogeneity of base composition of deoxyribonucleic acids: a compilation of old and new data. J. molec. Biol. 3, 3I. 